\title{
FABIANISM AND GUILD SOCIALISM: TWO VIEWS OF DEMOCRACY
}

In this century British socialism has rarely engaged in serious internal debate about the fundamental concepts of its political vocabulary. In this respect, as in others, British socialism has been true to the wider traditions of British political life. There has, of course, been much vigorous controversy on policy and programme, but also a remarkable absence of genuine doctrinal debate, certainly as compared with continental socialisms. A major exception to this, however, is to be found in the decade which has the First World War at its centre. Indeed, this may be regarded as the most creative period in British socialist thought in the twentieth century (notwithstanding the superficially more turbulent 1930's); and it is a period which ends, interestingly, in the early 1920's, when Labour becomes securely established in the world of parliamentary politics.

Within this period, it is the battle of ideas between an established Fabianism and a challenging Guild Socialism which has a particular interest and significance. The intellectual ascendancy of the Fabian doctrine of state socialism, first enunciated in the 1880's, came under increasing attack in the years before 1914. The attack came from many quarters, ranging from the industrial challenge of syndicalism to the academic offensive of pluralism. "Underlying these novelties", wrote Ernest Barker in 1915, "there is perhaps one common basis - a general reaction against 'the State'."1 It was this reaction which the theorists of Guild Socialism, notably the young Oxford academic G. D. H. Cole, expressed and developed in their assault on a prevailing Fabianism. In doing so, they forced the Fabians back to fundamentals in the search for a response, challenged their intellectual ascendancy over the labour movement and sketched an alternative model of a socialist society. It was an important moment for British socialism, not least because it was a time of genuine theoretical debate.

${ }^{1}$ E. Barker, Political Thought in England 1848 to 1914, revised ed. (London, 1928), p. 223. 
This is not the place to recount the story of the magnificent ideological battles fought at meetings, summer schools and in print between the Guild Socialist Rebels and the Fabian Old Guard. The story is both fascinating and funny. Beatrice Webb's diary charts each new outrage perpetrated by the Rebels, and the temptation to quote is irresistible. For example, she records the "frightfulness"-of the Guild Socialists at the Fabian Summer School in 1914: they

drank copiously and defiantly of the beer they ordered in, hoisted the Red Flag in front of the House and brought the Police Inspector to remonstrate with us for the uproarious singing of revolutionary songs at the station and in the market place, at the exact time when the great Keswick Evangelical Convention was arriving for the week of Religious Experiences. ${ }^{2}$

Such theatricals were deliberately designed to shock the Fabian orthodox, and did. (At one Fabian meeting an outraged veteran moved "that Mr. Cole be a cad".) But what is important here is that the Guild Socialists launched a sustained critique of Fabian doctrine, focusing on the notion of democracy. Intellectual battle was waged, and the whole discussion about the meaning and nature of democracy seems strikingly modern. Both sides had to lay bare their assumptions about the place of man in the social system, thereby also revealing assumptions about the nature of man and of social systems. Both sides invoked the teachings of theory and the lessons of experience. Almost simultaneously in 1920, both sides produced paper models of their preferred societies (the Webbs' Constitution for the Socialist Commonwealth of Great Britain and Cole's Guild Socialism Re-Stated) which, taken together, perhaps represent the high-water mark of optimistic social engineering. ${ }^{3}$

A word about G. D. H. Cole, a curiously complex figure. He is the intellectual maverick of British socialism, certainly its most prolific writer and perhaps its most consistently creative thinker. His socialism was learned from William Morris, which helps to explain his persistent refusal to be orthodox, his irreverence towards the doings of parliaments and bureaucrats, and the sheer intensity of his socialist faith. He wanted to reform, but never became a reformist. His lifelong commitment to a form of socialist pluralism represented, in a real sense, a sort of permanent opposition to the main tradition of British socialism. Hence to the orthodox

${ }^{2}$ B. Webb's diary, 31 July 1914, Passfield Papers, British Library of Political and Economic Science.

${ }^{3}$ A few years earlier the Webbs had made just this point: "in this making of plans for reform, we are apt, in the twentieth century, when no change seems out of the question, to be a little misled by our speculative freedom." What Syndicalism Means (supplement to The Crusade, 1912), p. 17. 
he seemed unreliable, not quite sound: the question was always "What is Cole up to now?" If his restless and encyclopaedic mind produced no classic theoretical treatise, it usually asked the right questions. $\mathrm{He}$ is the "sensible extremist" of British socialism (his own phrase), too sensible for some, too extreme for most. Certainly too extreme for the Webbs, to whom this young apostle of workers' control appeared as a dangerous fanatic. For his part, Cole waged a fierce campaign against Fabianism and all its works, first as the enfant terrible of the Fabian Society, and then as the intellectual leader of the Guild Socialist movement. ("I believe this is a rude letter: but I cannot write temperately of Fabians", wrote Cole to Beatrice Webb on one occasion, ${ }^{4}$ with characteristically ruthless honesty.) Here was the first sustained challenge to the intellectual hegemony of Fabianism over the labour movement, and it had to be answered.

The debate which followed is more complex than is often suggested by those people who see the Webbs merely as stubborn old bureaucrats, and the Guild Socialists as utopian dreamers with one foot in the Middle Ages. Guild Socialism, as it took shape on the eve of the First World War, forced the Fabians back to theory. It attacked the easy Fabian identification of collectivism with socialism, and denied that efficiency of production and justice of distribution were the twin foundations of the socialist position. In essence, the Guild Socialists - like Belloc, the syndicalists and the academic pluralists in their different ways - discovered that the Fabian State might succeed only in replacing the capitalist by the bureaucrat, producing a regime of distributive justice certainly, but with deadening consequences for the whole social world, in which the individual, as both worker and citizen, would be a passive recipient rather than active participant. It would be the Servile State predicted by Belloc or the Selfridge State anticipated by Cole.

In his Modern British Politics Samuel Beer nicely demonstrated the statism and paternalism which has dominated the thinking of both Labourism and Conservatism in Britain. On the Labour side, of course, it is Fabianism which has been the chief intellectual repository of this type of collectivism. Shaw reflects exactly this attitude to the state and to democracy in his contribution to the original Fabian Essays.

We have the distinctive term Social Democrat, indicating the man or woman who desires through Democracy to gather the whole people into the State, so that the State may be trusted with the rent of the country, and finally with the land, the capital, and the organization of the national

4 Cole to Beatrice Webb, 14 March 1917, Passfield Papers. 
industry - with all the sources of production [. . .], which are now abandoned to the cupidity of irresponsible private individuals. ${ }^{5}$

Here stand revealed some of the most distinctive assumptions of classical Fabianism. Individualism is the enemy: democracy is merely the method of change; the aim is to "gather the whole people into the State"; the State (not "state"!) will own, efficiently control and justly distribute. If this scenario seemed to leave little role for the individual worker and citizen in the making of social decisions, the reason was quickly supplied by Sidney Webb: "The objection to authority is a radical not a socialist objection." 6

To the Guild Socialists the Fabians stood for nationalisation without socialisation, a grim prospect. Cole delivered an eloquent verdict on the Fabian future. In The New Age, that brilliant journal of the Guild movement, he wrote:

If, after a voyage almost as lasting as that of the Flying Dutchman, we round in the end the Cape of State Capitalism, we shall only find ourselves on the other side in a Sargossa Sea of State Socialism, which will continue to repress all initiative, clog all endeavour, and deny all freedom to the worker. ${ }^{?}$

The Guild Socialists thought they would not like to live in that sort of world, and that the worker would not like it either. They therefore developed a scheme of socialist democracy, which sought to transform every area of social activity - most immediately and crucially, the workplace into an arena of democracy. The aim was to prevent that loss of individuality and citizenship inherent alike in capitalism and state socialism.

If the individual is not to be a mere pigmy in the hands of a colossal social organism, there must be such a division of social powers as will preserve individual freedom by balancing one social organism so nicely against another that the individual may still count. ${ }^{8}$

Here was a challenge to Fabianism which was not simply a matter of different views about the appropriate constitutional machinery for a socialist state, but of fundamentally different conceptions about both socialism and democracy, and of their relationship. Fabian and Guild Socialist could agree that political democracy implied (and was largely nullified without) economic democracy, and that democracy and socialism

5 G. B. Shaw, "Transition", in: Fabian Essays in Socialism (London, 1889), p. 182.

6 S. Webb, A Stratified Democracy (a Fabian Society lecture on 14 November 1919, published as a supplement to The New Commonwealth, 28 November 1919), p. 8.

7 "Nationalisation and the Guilds", in: The New Age, 10 September 1914.

8 Cole, Self-Government in Industry (London, 1917), p. 139. 
were thus two sides of the same coin. But this agreement on terms barely disguised the deep disagreement on their content. During its formative period, Fabian Socialism never had to confront the problem of democracy in any fundamental way, except to brush aside the claims of anarchists or Marxists. As Sidney Webb conceded in 1919, "Socialists have contributed so far very little to the theory or practice of Democracy"; they have been "accepting uncritically the ordinary Radical idea of democracy" ${ }^{9}$ It was this uncritical acceptance which Guild Socialism destroyed, leading the Webbs to point out in their "Socialist Constitution" that in the early twentieth century there occurred "a revolution in thought with regard to the nature of Democracy". ${ }^{10}$ The aim here is not to give a full account of Fabian or Guild doctrine, but to focus on those aspects of the democratic theory of Guild Socialism which seem to conflict most fundamentally with the assumptions of Fabianism and which raise some of the permanent problems of democratic theory.

For example, it is clear that the conception we have of the nature and development of a social system will have important consequences for our view of democracy. For the Webbs, society is an evolving organism and a key aspect of this evolution is the "organic differentiation of function". This differentiation is both political and economic. In the one case, it is seen in the development of representative government, alike in the political and industrial world, instead of the old "primitive" democracy, which encouraged legislative instability and administrative weakness. The Webbs concede that this professionalisation of the representative function does mean that the representative loses "that vivid appreciation of the feelings of the man at the bench or the forge", but this is the "cruel irony". ${ }^{11}$ In the other case, differentiation appears as the increasing specialisation and division of labour of modern production. So here is an argument "from the centre" (of the kind which has become more familiar in recent years, but which is as old as Plato): activities and individuals are defined in terms of the needs of a developing social system. Of course these "needs" can be many and various. For example, the defining principle can be military power or social stability, or - with the Webbs - social efficiency and distributive justice; but in each case the argument begins at the centre and moves outwards to embrace institutions, groups and individuals.

The Guild Socialists, especially Cole, sought to challenge this whole approach to social theory. Society was not like anything else, not organism

9 S. Webb, A Stratified Democracy, op. cit., p. 2.

${ }_{10} \mathrm{~S}$. and B. Webb, A Constitution for the Socialist Commonwealth of Great Britain (London, 1920), p. xiv.

11 S. and B. Webb, Industrial Democracy (London, 1897), p. 56. 
or mechanism or any other analogy. It had to be analysed in its own terms, and especially in terms of the needs and wills of the individuals who composed it. Cole expressly declared himself to be engaged in normative social philosophy, and Guild theory is heavily idealist and voluntarist. For instance, Cole attacked the "deadening determinism" of Marx, and stressed the role of ideas and theory.

Only an idea can slay an idea: until the workers are animated with the desire to be their own masters they cannot supplant the idea that their class is born for wage-slavery. ${ }^{12}$

In contrast to Fabian theory, the Guild Socialist man has considerably more power to construct his own social world. The divorce of work from art, the division of labour, the wage system, industrial autocracy: these are not to be seen as inevitable (let alone progressive) aspects of modern social organisation, but as obstacles to personal development and social fellowship, which could and should be removed by a democratic social and industrial structure. This view struck at the roots of a Fabianism which embraced all these developments as necessary and welcome ingredients of a progressive social organism, and which therefore saw Guild Socialism as not merely undesirable or impracticable but as historically regressive.

But the organic evolutionism of the Fabians was itself rooted in a complex of beliefs and assumptions - about work, discipline, authority, moral character, and crucially about the nature of man himself - which had decisive consequences for their view of the desirability or possibility of a democratic social order. A basic and constant charge made by Guild Socialism against the Fabians was that they had a fundamental distrust of ordinary people and little understanding of their aspirations. The Webbs certainly devoted vast volumes to the study of working-class organisations, but rather in the manner of anthropologists investigating an interesting tribe. In 1894 Beatrice had noted in her diary: "we have little faith in the 'average sensual man', we do not believe that he can do much more than describe his grievances, we do not think that he can prescribe his remedies." 13 When the syndicalist movement did announce a prescription by the average sensual worker of his own remedies, the Webbs - very much in the tradition of Tocqueville, Mill and more modern theorists raised the spectre of "small minorities" of workers with special needs being "swamped" by the "mass" of workers who exert a majoritarian tyranny.

It was the manual worker who was particularly to be feared.

13 B. Webb, Our Partnership (London, 1948), p. 120. 
I often wonder [wrote Sidney Webb] when I hear my Guild Socialist friend talk about the right of the workman to control his own work, to exercise authority over his own sphere, when we shall have a revolt of the technician, the electrician, the chemist, the artist, the designer, the manager. We, too, want to have self-determination; we want to have control over our working life. ${ }^{14}$

It would be easy to document countless instances of Webbian fear and suspicion of workers in the aggregate, and of the need to discipline workers in the interest of social order. For example, syndicalism is indicted for preaching to the workers "a deliberate disregard of the duties of citizenship", while the methods of syndicalism could only mean "a serious deterioration of moral character in those who consent to take part in it". ${ }^{15}$

Even much later, when the Webbs - under the Guild challenge - have moved to a position much more critical of merely geographical or consumer democracy, this shift did not mark any significant change in their opinion of the ordinary man's democratic possibilities. For example, in his interesting and important lecture in 1919 on A Stratified Democracy, Sidney Webb declared that democracy of the geographical variety

inevitably means the submerging of the active spirits in what the French call the apathetic mass. The great mass of people will always be found apathetic, dense, unreceptive to any unfamiliar ideas, and your eager active spirit with the unfamiliar idea [...] frets and fumes at being held in check by this apathetic mass. But, after all, the apathetic mass are individually God's creatures, and entitled to have a vote, and it is no use kicking against their apathy and denseness; you have got to work your governmental machine in some way that will enable you to get on notwithstanding their denseness. ${ }^{16}$

Here is a splendid glimpse into Webbian sensibility, not least in its suggestion that the entitlement to a vote is the hallmark of our divine pedigree.

Denouncing what they called this "Fabian heresy of distrust", the Guild Socialists were loud in proclaiming their trust in both the capacity and the character of the average sensual man. The Fabian assumption was always that men were likely to exploit each other unless there were firm institutional safeguards provided by the community at large. The Webbs write constantly of the dangers presented by sectional selfishness and exclusiveness, above all the selfishness of groups of manual workers; and they offer this insight into the selfishness of organised groups as a lesson of history, revealed in ancient castes and medieval guilds no less than in the modern world. Industrial self-government would therefore give a blank

14 S. Webb, A Stratified Democracy, p. 7.

15 S. and B. Webb, What Syndicalism Means, op. cit., p..11.

16 A Stratified Democracy, p. 5. 
cheque to producer groups to exploit each other and the community of consumers. The golden rule in this respect was to be found in "the homely adage that no man can be trusted to be judge in his own case". ${ }^{17}$ At present, they believe, the sectional selfishness of groups of workers was only held in check by the need to unite against the common capitalist enemy, though even now demarcation disputes gave some indication of what would happen if the trade union developed into an organ of government.

In fact, the Guild Socialists did not propose to dispense with institutional safeguards against possible sectional exploitation. They were especially anxious to remove fears about the fate of the consumer under a system of industrial democracy. Much of Guild Socialist system-building was centrally concerned with the elaboration of the proper balance in each sphere and at every level between legitimate social interests, particularly the interests of producers and consumers. Cole's Guild Socialism Re-stated stands as a monument to this concern. But it was always insisted that the purpose of such elaborate social machinery was not to "protect" the consumer from the producer - for that would imply a natural human tendency to exploit - , but simply to provide machinery whereby consumer needs and desires could be communicated to the Guilds of producers. The effect might be the same; the difference of approach was important. The Guild Socialist man is seen as having a "natural" tendency towards fellowship, thwarted only by a divisive social environment; Fabian men need protection from each other.

The Guild Socialist man is also a "natural" democrat, in the sense both that he is fit to control his own social environment and that he demands those personal and social benefits - dignity, creativity, self-development and the rest - which are the fruits of an actively democratic social world. By contrast, as we have seen, the Fabian man - not the expert or the professional representative, but the average sensual man - is fitted only to express his demands and grievances. This argument, classicly developed by Aristotle, is that even the simplest men know where the shoe pinches (they can feel if not think): from which can be derived the position that men should have a "say" in government (in modern times, a vote), but that they should have no more than this. They express their needs by passing retrospective verdicts on external prescriptions. The implications for democratic theory are clear, and were spelled out by the Webbs in their critical analysis of various devices for making democracy more directly participatory. "What Democracy requires is assent to results; what the Referendum gives is assent to projects. "'18 To the Guild Socialist, democracy was about process

17 S. and B. Webb, The Consumers' Co-operative Movement (London, 1921), p. 465.

${ }^{18}$ S. and B. Webb, Industrial Democracy, op. cit., p. 61. 
as much as product: it was both natural and necessary that men were actively engaged in the making of social decisions, or they lost part of themselves. Especially was this true of industry, where for the mass of workers "the sense of being owned is deadening". ${ }^{19}$ Guild Socialists always insisted on the benefits of industrial democracy in terms of "product" too, especially efficiency - denying that men will do good work in the absence of conditions of self-government -, but it was democracy as process that remained central.

The foundation of the democratic theory of Guild Socialism - perhaps its greatest contribution to that theory - was its analysis of the concept of representation, particularly as developed by Cole. The democratic idea, it was alleged, had got lost over time in a false theory of representation, which claimed that one man could "represent" another. It was a false and dangerous theory which said that man as a "whole" could be represented, when all that could really be represented was particular functions and purposes which men have in common. The concept of function was the "real and vital principle of democracy", ${ }^{20}$ not to be confused with the sort of functionalist social theory, stretching from Plato to the Webbs (and now familiar in much contemporary theory), which defines individuals and institutions in terms of the requirements of a particular social system, and which therefore acts as an agency of social control. Guild theory made nonsense of any theory of state sovereignty, for the state was simply a functional association like any other, formed for a particular purpose. It was merely "one among a number of forms of association in which men are grouped according to the purposes which they have in common", ${ }^{21}$ and belonged to the same category as trade unions, churches, football clubs and the host of other associations which command our membership and loyalties. The state was not universally sovereign, nor did we derive our rights from it; for sovereignty was diffused throughout the entire community, which was the locus of our rights and obligations.

Genuine democracy would only be realised in a system of co-ordinated functional representation. The Guild argument was not an anarchic attack on the concept of representation itself, but an attack on the current misuse of the concept contained in the doctrine that in one single and general act man as a whole could be "represented". In fact, men should be represented in all their multiple functional associations and loyalties, requiring an elaborate and co-ordinated representational structure throughout society.

19 Cole, The World of Labour (London, 1913), p. 419.

20 Cole, Labour in the Commonwealth (London, 1918), p. 201.

21 Cole, Self-Government in Industry, p. 129. 
It might be noted in passing that Guild Socialism did embody a general social theory, and was not confined merely to the industrial scene. Just as democracy could not be confined to politics, nor could it end with industry: it was a general theory of social organisation. In Cole's words, the democratic principle applied "not only or mainly to some special sphere of social action known as "politics', but to any and every form of social action". ${ }^{22}$ Hence his radical proposal for self-government in the classroom, involving considerable pupil control over curriculum, discipline, teaching methods and other aspects of school life. "Until a large measure of students' selfgovernment is developed", he wrote, "democracy in the school will not be realised and the power of education as a liberating influence will not have been properly developed." 23

The conception of representation developed by Cole carried with it a view of the conditions in which representation would be genuinely effective and of those in which misrepresentation would necessarily result. The golden rule in this matter was that representation must be "specific and functional", not "general and inclusive". Misrepresentation occurred when the purposes for which the representative was chosen lost clarity and precision. In this matter parliament was the worst offender because it "professes to represent all the citizens in all things, and therefore as a rule represents none of them in anything". ${ }^{24}$ Men could best control those things in which they were most closely involved and which they best understood: here was the arena for effective representation. It is interesting that Schumpeter later made a very similar point, though of course without arriving at a similar conclusion about the need to "socialise" the representative function. ${ }^{25}$

A comparison with the Webbs at this point is particularly revealing, for they were concerned to argue a directly contrary position about the conditions for democratic representation. It was

22 Cole, Guild Socialism Re-stated (London, 1920), p. 12.

23 Ibid., p. 112.

24 Cole, Social Theory (London, 1920), p. 108.

25 According to Schumpeter, a person's judgement will be best in relation to "the things which are familiar to him independently of what his newspaper tells him, which he can directly influence or manage and for which he develops the kind of responsibility that is induced by a direct relation to the favourable or unfavourable effects of a course of action". However, lest this should be construed as an argument favourable to radical democracy, Schumpeter later declares: "No responsible person can view with equanimity the consequences of extending the democratic method, that is to say the sphere of 'politics', to all economic affairs." J. Schumpeter, Capitalism, Socialism, and Democracy (London, 1942), pp. 259, 299. 
the supreme paradox of democracy that every man is a servant in respect of the matters of which he possesses the most intimate knowledge, and for which he shows the most expert proficiency, namely, the professional craft to which he devotes his working hours; and he is a master over that on which he knows no more than anybody else, namely, the general interests of the community as a whole. In this paradox [. . . lies at once the justification and the strength of democracy. ${ }^{26}$

To which the Guild Socialist reply was that democracy of this type had become generally acceptable to all classes simply because it had so obviously failed, serving only to deprive the ordinary worker and citizen of any effective role in the determination of his social environment. The need now, said the Guild Socialists, was to inject democracy into the workplace, which would then become a laboratory and base from which men would learn to control the wider society (the individual, "in learning to control his own industry, [. . .] would learn also to control the political machine") ${ }^{27}$ which would be a black day indeed for those lampooned by Cole as "the bureaucratic jugglers in human lives whom we still call statesmen - or sometimes New Statesmen". ${ }^{28}$

It is important to notice how this whole controversy between Guild Socialism and the Fabians over the question of democracy was an intricate mixture of values and potentially testable empirical judgements. Even Cole's explicitly normative position was affected, as he pointed out himself, by such things as the findings of social psychology. The Webbs declared an impossible relationship between manager and workers in a democratic factory:

The relationship set up between a manager who has to give orders all day to his staff, and the members of that staff who, sitting as a committee of management, criticise his action in the evening, with the power of dismissing him if he fails to conform to their wishes, has been found by experience to be an impossible one. ${ }^{29}$

It was all said to be "a matter of psychology"; but we may well want to look a little more closely at the exact nature of this psychological impossibility before accepting it as axiomatic. The Webbs also invoked the lessons of history to suggest a terrible inevitability about the failure of all "selfgoverning workshops" (of which they believed Guild Socialism to be merely the latest variant). Beatrice had written off the idea of the self-

${ }^{26}$ S. and B. Webb, Industrial Democracy, p. 844.

27 Cole, Self-Government in Industry, p. 185.

28 Cole, "Freedom in the Guild", in: The New Age, 5 November 1914.

${ }^{29} \mathrm{~S}$. and B. Webb, A Constitution for the Socialist Commonwealth, op. cit., p. 161. 
governing workshop as "that 'charmer' within 'the order of thought' but 'gay deceiver' within 'the order of things"', 30 and she and Sidney set out to document this early verdict. ${ }^{31}$ Cole's reading of history was rather different, leading him to deny that the self-governing feature of the selfgoverning workshop was the decisive factor in their demise, and to emphasise instead the capitalist environment in which they operated. So here too was an area in which we might be able to furnish some evidence which would have some bearing on the argument.

There were many other propositions of both the Guild and the Fabian position which may be open to some form of empirical testing. For example, is it true, as the Webbs maintained, that the vocational tie is stronger than that of an industry as a whole, so that it is "for his vocation that every worker intuitively aspires to all the self-determination that can be attained". ${ }^{32}$ Would a vocation or craft rather be subject to the decision of the whole community than to be part of a single industry democracy, so that "paradoxically" Guild Socialism turns out to be "actually incompatible with 'workers' control' in its most legitimate and [. . .] highest sense"? ${ }^{33}$ On the other hand, is it true, as the Guild Socialists maintained, that democracy in industry would release a democratic vitality in the wider society? What of Cole's oft repeated adage that "a taste of control will produce a taste for control"? Can we properly attribute apathy about politics to the lack of democracy in industry? Is it true that "over the vast mechanism of modern politics the individual has no control, not because the State is too big, but because he is given no chance of learning the rudiments of self-government within a smaller unit"? ${ }^{34}$ Would democracy in industry succeed in making the factory less of "a mere prison of boredom and useless toil", or does the nature of modern production make democracy irrelevant in this respect? Would a system of functional democracy produce that flowering of art and science, taste and appreciation, predicted by the Guild Socialists? At a basic level, do men want to control the conditions of their working life and to assume the responsibilities which go with such control?

Finally, Guild Socialists and the Webbs came to differ fundamentally on an even more basic issue: how important was the work situation anyway? It

${ }^{36}$ B. Webb, My Apprenticeship (London, 1926), p. 377.

${ }^{31}$ Cf. "Why the Self-Governing Workshop has Failed", Appendix E to My Apprenticeship, pp. 446-53. The Webbs also produced a New Statesman supplement on "Cooperative Production and Profit-sharing" (14 February 1914), which critically surveyed the history of this type of experiment.

${ }^{32}$ S. and B. Webb, The Consumers' Co-operative Movement, op. cit., p. 471.

${ }^{33}$ Ibid., p. 472.

${ }^{34}$ Cole, "Freedom in the Guild", ibid., 12 November. 
was a cardinal tenet of Guild Socialism that the lack of real industrial democracy induced in man a stultifying psychology of servility which went far beyond the factory gate. But the Webbs insisted that a man's real enslavement was during his unproductive and non-producing years:

It is not so much in the hours of work that a manual working man or woman [...] at present suffers: it is in the limitations which his present penury sets to his use of his hours of leisure. ${ }^{35}$

By concentrating on the conditions under which production was carried on, Guild Socialism was said to be a crudely materialist doctrine; whereas state socialism would provide the resources for a fuller and freer life for the whole.community. It is clear from this that an analysis of the social and psychological significance of work has important consequences for prescriptive theory.

But these are all problems which are easier to identify than resolve. Here it is suggested only that we might be able to assemble evidence which would have some bearing on some of the arguments which were used by both sides in this debate about democracy. ${ }^{36}$ Indeed, this approach is true to Webbian methodology itself, and was used by the Webbs in 1920 to justify their shift to a position far more favourable to the general notion of trade-union participation in the management of industry. The abolition of the wage system was now recognised as an abiding working-class aspiration, and a democracy of consumers was acknowledged to suffer from "the outstanding defect to the manual-working producer that, so far as his own working life is concerned, he does not feel it to be Democracy at all!"37

In an appendix to the 1920 edition of their History of Trade Unionism, the Webbs identified three main factors causing them to modify their earlier absolutist opposition to producer participation in industrial control. These were 1) the growth among manual and technical workers of "corporate self-consciousness and public spirit" (rather than the corporate selfishness which the Webbs had previously laid down as axiomatic), 2) the diffusion of education, and 3) further discoveries in the technique of democratic institutions, above all the technique of devolving responsibility to organised groups. This last point is especially important, for it marked a shift in the Webb position from the old one-dimensional collectivism to a new group view of the political process. This shift was clearly spelled out in

35 S. and B. Webb, What Syndicalism Means, p. 19.

36 Useful approaches along these lines are to be found in C. Pateman, Participation and Democratic Theory (Cambridge, 1970), and P. Blumberg, Industrial Democracy: The Sociology of Participation (London, 1968).

37 S. and B. Webb, The History of Trade Unionism, revised ed. (London, 1920), p. 711. 
Sidney Webb's lecture on $A$ Stratified Democracy, where political decisions were seen increasingly to be the result of a process of "going to the group" rather than to the traditional channels of parliamentary and geographical democracy. Guild Socialism was seen as one expression of the group idea, but defective because of its narrow focus on the industrial working class. What was needed was a theory of democracy which combined an active role for organised groups with the best elements of the traditional geographical representation. In their "Socialist Constitution", the Webbs offered their own considered version of such a democracy.

The condition of any genuine Democracy, of the wide diffusion of any effective freedom, is such a systematic complication of social machinery as will negative alike the monarchical and the capitalist dictatorships, and prevent the rise of any other. The price of liberty [. . .] is the complication of a highly differentiated and systematically co-ordinated social order. ${ }^{38}$

So here was a Fabian pluralism, strikingly similar - at least in spirit - to the "democratic pluralism" of more recent vintage.

It remains to say something about the extent to which Fabian and Guild thinking on the problem of democracy arrived at some sort of synthesis by around 1920. This was the Fabian claim - indeed Fabianism, not unlike Hinduism, liked to boast of an amorphousness which enabled it to contain and embrace rival doctrines. Thus, according to Shaw, the alleged antithesis between Guild Socialism and Fabian collectivism was "imaginary" and "vanished at the first touch of the skilled criticism the Fabians brought to bear on it". ${ }^{39}$ But did it? Certainly the Webbs have travelled a considerable distance from their Industrial Democracy of 1897 to their "Socialist Constitution" of 1920 , but have they really arrived at a different destination?

It is true that in their later writings they do accept a Guild Socialist definition of the crucial issues to be tackled. Terminology reflects this change: there is less talk of efficiency, waste, anarchy, individualism, poverty and the rest of the Fabian stock-in-trade, and much more of power, status and authority. It is the distribution of power which is now accepted as central:

the central wrong of the Capitalist System is neither the poverty of the poor nor the riches of the rich; it is the power which the mere ownership of the instruments of production gives to a relatively small section of the com-

38 A Constitution for the Socialist Commonwealth, p. 202.

${ }^{39}$ G. B. Shaw, "On Guild Socialism", in: E. R. Pease, The History of the Fabian Society (London, 1916), p. 266. 
munity over the actions of their fellow-citizens and over the mental and physical environment of successive generations. ${ }^{40}$

Accepted too is Cole's analysis of the nature of representation, and the Webbs devise schemes for representing men in each of their leading functional roles. They stress the value to men of democratic participation. Democracy now was necessary, not merely for the expression of grievances or to check abuses of power, but crucially for "that development of personality, and that enlargement of faculty and desire dependent on the assumption of responsibility and the exercise of will"41 - in industry no less than in politics. The Webbs would now yield to no-one in their enthusiasm for the democratic cause.

But this acceptance by the Webbs of the basic categories of the Guild Socialist argument scarcely disguised the fact that they were as far as ever from accepting the implications of that argument. The old authority relationships, once thought indispensable to industrial efficiency, could now be largely abandoned - but only because decisions were now seen as "emerging" from a consultative process in which the stream of reports from disinterested experts would exercise decisive influence. Of course, the representatives of the workers would find a place in the decision-making process. Perhaps literally a place: "It is a real social gain", wrote the Webbs, "that the General Secretary of the Swiss Railwaymen's Trade Union should sit as one of the five members of the supreme governing body of the Swiss railway administration." 42 We may wonder how participation of this order would produce that widespread "development of personality [...] dependent on the assumption of responsibility and the exercise of will" which the Webbs now believed was so important.

The truth is, it seems, that the harmony model of the Webbs was seen as making redundant most of the traditional arguments about democracy. Authority was to be transformed by being universalised: what would disappear would be personal authority, for all were servants now. ("There is something rather fine in the heraldic motto of the Prince of Wales, 'I serve" - Sidney Webb. ${ }^{43}$ ) The old problem of "government from above"

$40 \mathrm{~S}$. and B. Webb, A Constitution for the Socialist Commonwealth, p. xii. Pease, the official Fabian historian, identified poverty and its elimination as the key Fabian objective (The History of the Fabian Society, p. 257). Now, however, the Webbs seem closer to Cole's view that "Socialists have all too often fixed their eyes upon the material misery of the poor without realising that it rests upon the spiritual degradation of the slave" (Self Government in Industry, p. 35).

${ }^{41} \mathrm{~S}$. and B. Webb, ibid., p. 100.

42 S. and B. Webb, The History of Trade Unionism, op. cit., p. 760 (appendix on "The Relationship of Trade Unionism to the Government of Industry").

${ }^{43}$ S. Webb, A Stratified Democracy, p. 8. 
versus "government from below" was now dissolved in a common subservience to the community and to facts. What this meant for authority relationships at work was delightfully expressed by Sidney:

The manager, instead of saying to one man "Go", and he goeth, to another man "Do this", and he has to do it, will give him his job to do, tell him how to do it, and leave him to do it in his own way; just what a reasonable person does with his cook. ${ }^{44}$

Vocational self-determination turned out merely to be the right of a vocation to be consulted in matters which directly concerned that vocation; and the model of a vocation as conceived by the Webbs was much closer to the British Medical Association or even the Jockey Club than to an industrial trade. The community was still king; and organised democracy would simply allow and encourage functional groups to develop a professional ethic in the common interest. Instead of subverting social harmony, democracy turned out to reinforce it; and so all were democrats now.

Of course, Guild Socialism was in many respects a harmony model too. If the Webbs largely managed to dispense with democracy, Cole perhaps managed to make it a little too easy. One reason for this was his belief in the human benefits of democratic activity itself, a belief - akin to that of the younger Mill - in participation as a school of moral discipline and development. This bestowed an importance on the principle which no structural difficulties would be allowed to devalue. Thus, in Cole's scheme, the functional principle integrated as well as separated, and there was a tendency to define group activity in terms of the proper performance of social function, thereby producing a deceptively minimal amount of inter-group conflict and a deceptively easy process of social adjudication and coordination. There was also a tendency to assume that because men shared a common area of interest they would also share a common policy position inside that area; whereas in fact proximity of interest and knowledge might well increase the scope for disagreement. This might be no bad thing of course, but it does require some consideration of the mechanisms of opinion formation and policy formulation inside democratic organisations and within the wider society. There was therefore an element of "imposed" pluralism in Cole's scheme, but this was perhaps inevitable in this sort of system-building, as Cole was well aware. The aim was not to develop a refined constitutional structure, but to suggest what a society which genuinely took democracy as its central organising principle might in fact look like.

This involved a number of important propositions that still seem rele${ }^{44}$ Ibid. 
vant. For example, that even if the class character of existing society was abolished, it would still fail to meet the conditions of reasonable human association; that representative democracy must be a complex social process and not a single general act; that while everything may be everyone's concern, some things concern some people in special ways (it affects everyone how the coal mines are run, but it affects the miners in a special way); that unless a man feels a sense of freedom at his work he will not enjoy freedom in the wider society either; that the future of society is better trusted to an active social democracy than to a band of disinterested experts - and so on.

A final proposition, of course, was that Fabian collectivism would meet none of these conditions of the good life. Guild Socialism denied what Fabianism asserted - that in mass industrial society man necessarily loses control over his own life and immediate circumstances and finds his own true freedom only in service to the wider community. A central problem for democratic and socialist theory is at issue here. What is to be the size of the democratic unit? Can a collective control compensate for the loss of a more direct control over social life? On this basic issue the Webbs never wavered. They shed no tears over the demise of the old direct or "primitive" democracy, for it produced only anarchy and turbulence. The rise of socialism was important above all else because it suggested the possibility of regaining collectively what had been lost individually. ${ }^{45}$ The real change involved in the transition to socialism had ultimately little to do with authority relationships or the nature of work, but with the expropriation of capitalist surplus value by a state which would then provide the material resources for a fuller life for the whole community. A whole definition of socialism was involved here, a definition challenged by the Guild Socialists in the name of democracy, thereby earning for themselves the castigation of the Webbs as

those impatient democrats who will not take the trouble to understand the problem, and who petulantly demand, at the same time, the elaborations and refinements of civilisation and the anarchy and simplicity of the primitive age. ${ }^{46}$

This difference of theory clearly involved important consequences for policy. Just one of these can be mentioned in conclusion. Guild Socialism embraced the trade unions as the nucleus of future industrial self-govern-

45 "But the very fact that, in modern society, the individual thus necessarily loses control over his own life, makes him desire to regain collectively what has become individually impossible." Industrial Democracy, p. 850.

46 S. and B. Webb, A Constitution for the Socialist Commonwealth, pp. 201-02. 
ment and sought to develop techniques of effective representation inside these democratic Guilds. The Webbs also believed that trade unions would and should cease to be merely defensive organisations: their task would be to develop techniques for improving their professional service to the community, and to mobilise that consciousness of consent among workers which was vital for the modern production process. What the trade unions would not be allowed to do was to interfere with the interests of the community. So in their Industrial Democracy (which, despite its title, is just a study of the government of trade unions) we find this revealing and prophetic statement by the Webbs of the role of the organised workingclass movement in their fully democratic society: trade-union activities would become "increasingly subject to the fundamental condition that the business of the community must not be interfered with", so that we may expect that "whenever an industrial dispute reaches a certain magnitude, a democratic state will, in the interests of the community as a whole, not scruple to intervene, and settle the points at issue by an authoritative fiat. The growing impatience with industrial dislocation, will, in fact, where Collective Bargaining breaks down, lead to its super-session by some form of compulsory arbitration; that is to say by Legal Enactment."47 Recent events in British politics might suggest that, at least in this respect, the Fabian state has arrived.

${ }^{47}$ Industrial Democracy, pp. 813-14. 